\title{
ANALISIS YURIDIS TERHADAP PELAKSANAAN PERDA NOMOR 7 TAHUN 2012 TENTANG RTRW KABUPATEN KARIMUN YANG TERBIT SEBELUM DITERBITKAN/DISAHKAN PERDA NOMOR 1 TAHUN 2017 TENTANG RTRW PROVINSI KEPULAUAN RIAU
}

\author{
Maryeni Defrita*, \\ Dinas Pekerjaan Umum dan Penataan Ruang
}

\begin{abstract}
Abstrack
The law is an important instrument in a country. The law is the legal basis that forms the basis of all policies made by the government. In compiling a local regulation, it must be sourced from the rules above it so that it must not conflict with the rules above it. This study uses qualitative methods of imprint juridical, impirical juridical law research examines the implementation of positive legal provisions in each particular law. Namely reviewing the Spatial Planning Law related to Regional Regulation No. 7 of 2012 concerning the Spatial Planning of Karimun Regency which was published before the Establishment of Regional Regulation No. 1 of 2017 concerning Spatial Planning for the Riau Islands Province. The results showed that in the preparation of spatial plans. according to UUPR article 25 paragraph (1) Preparation of Regional Regulations on the Regency Spatial Planning must refer to the provincial spatial plan and national spatial plan. the issuance of Regional Regulation Number 7 of 2012 concerning Spatial Planning for Karimun Regency which was issued before Regional Regulation Number 1 of 2017 concerning Spatial Planning for Riau Islands Province. Discrepancies were found in the spatial and forest allotment maps between Karimun Regency and Riau Islands Province, resulting in the absence of legal certainty.
\end{abstract}

Keywords - Legal certainty, RTRW

\begin{abstract}
Abstrak
Undang-undang merupakan instrumen penting dalam suatu negara. Undangundang merupakan landasan hukum yang menjadi dasar pelaksanaan dari seluruh kebijakan yang dibuat oleh pemerintah. Dalam menyusun suatu perda harus bersumber dari aturan di atasnya sehingga ia tidak boleh bertentangan dengan aturan di atasnya. Penelitian ini mengunakan metode kualitatif yuridis impiris, penelitian hukum yuridis impiris mengkaji pelaksanaan ketentuan hukum positif pada setiap hukum tertentu. Yaitu mengkaji tentang Undang-undang Penataan Ruang dikaitkan dengan Peraturan Daerah Nomor 7 tahun 2012 tentang Rencana Tata Ruang Wilayah Kabupaten Karimun yang diterbitkan sebelum Pembentukan Peraturan Daerah Nomor 1 tahun 2017 tentang Rencana Tata Ruang Wilayah Provinsi Kepulauan Riau. Hasil penelitian menunjukan bahwa dalam penyusunan rencana tata ruang. menurut UUPR pasal 25 ayat (1) Penyusunan Perda Rencana
\end{abstract}

*Alamat Korespondensi : maryeni.defrita@yahoo.co.id 
Tata Raung Kabupaten harus mengacu kepada rencana tata ruang provinsi dan rencana tata ruang nasional. terbitnya Peraturan Daerah Nomor 7 Tahun 2012 tentang Rencana Tata Ruang Wilayah Kabupaten Karimun yang diterbitkan sebelum Peraturan Daerah Nomor 1 tahun 2017 tentang Rencana Tata Ruang Wilayah Provinsi Kepulauan Riau. Ditemukan ketidak sesuaian pada peta pola ruang dan peruntukan hutan antara Kabupaten Karimun dengan Provinsi Kepulauan Riau, sehingga mengakibatkan tidak adanya kepastian hukum.

\section{Kata kunci- Kepastian hukum, RTRW}

\section{A. Latar Belakang Masalah}

Undang-undang adalah instrumen penting dalam suatu negara. Undangundang merupakan landasan hukum yang menjadi dasar pelaksanaan dari seluruh kebijakan yang dibuat oleh pemerintah. Legal policy yang dituangkan dalam undang-undang menjadi sebuah rekayasa sosial yang memuat kebijakan yang hendak dicapai pemerintah, untuk mengarahkan masyarakat menerima nilai- nilai baru . Dalam Perundang-undangan dikenal dengan hirarkhi norma hukum atau penjenjangan norma hukum. Teori mengenai jenjang norma hukum ini dikaitkan dengan ajaran Hans Kelsen tentang stufentheory yang mengatakan bahwa suatu norma yang lebih rendah berlaku, bersumber dan berdasarkan pada norma yang lebih tinggi, norma tersebut juga bersumber dan berdasarkan kepada norma yang lebih tinggi lagi dan seterusnya sampai pada suatu norma yang tidak dapat ditelusuri lebih lanjut yang sifatnya hipotesis atau fiktif yaitu norma dasar (grundnorm) .

Untuk mewujudkan pembangunan agar dapat menjadi pendukung antar berbagai sektor suatu daerah maka diperlukan suatu arahan agar pembangunan dapat dilakukan secara maksimal untuk meningkatkan kesejahteraan masyarakat suatu daerah tertentu. Untuk mendukung dan mendorong konsep dalam rangka pelaksanaan otonomi daerah di bidang penataan ruang, maka kemandirian daerah menjadi penting dalam hal perencanaan yang meliputi konsep kawasan, pembangunan berkelanjutan dan amdal, maka daerah diberi kewenangan untuk menggali potensi yang ada di daerahnya, salah satu dari kewenangan itu adalah melakukan perencanaan tata ruang sesuai dengan keadaan ruang wilayahnya.

Kabupaten Karimun lahir dari hasil pemekaran Kabupaten Kepulauan Riau berdasarkan UU No.53 Tahun 1999 tentang pembentukan Kabupaten Pelalawan, Kabupaten Rikan Hulu, Kabupaten Rokan Hilir, Kabupaten Siak, Kabupaten Karimun, Kabupaten Natuna, Kabupaten Kuantan, Sengingi dan Kota Batam adalah merupakan manivestasi dari pelaksanaan otonomi daerah dan perkembangan dinamika kehidupan untuk berdiri sendiri dalam suatu wilayah Kabupaten dalam Negra Kesatuan Republik Indonesia.

Berdasarkan luas wilayahnya, Kabupaten Karimun merupakan daerah kepulauan mempunyai luas 7.984 kilometer persegi dan terdiri dari wilayah daratan seluas 1.524 kilometer persegi dan daerah perairan 6.460 kilometer persegi. Kabupaten Karimun mempunyai kateristik geografis dan kedudukan yang sangat 
strategis dan memiliki keanekaragaman ekosistim serta potensi sumber daya alam yang tersebar luas yang dapat dimanfaatkan secara terkoordinir terpadu dan selektif tetap memperhatikan faktor politik, ekonomi, sosial budaya, pertahanan keamanan serta kelestarian lingkungan hidup untuk menopang pembangunan dan pengembangan wilayah yang bersifat akomodatif dan komperhensif untuk mendorong proses pembangunan daerah secara berkelanjutan berdaya guna dan berhasil guna.

Untuk mewujudkan tujuan tersebut maka Pemerintah Kabupaten Karimun mengaturnya dalam suatu Peraturan Daerah Nomor 7 Tahun 2012 Tentang Rencana Tata Ruang Wilayah Kabupaten Karimun dalam rangka pelaksanaan penyelenggaraan otonomi daerah yang merupakan jabaran lebih lanjut dari peraturan perundang-undangan yang lebih tinggi yaitu pasal 25 Undang-undang Nomor 26 Tahun 2007 Tentang Penataan Ruang. Rencana umum tata ruang kabupaten/kota adalah penjabaran Rencana Tata Ruang Wilayah Provinsi kedalam kebijakan dan strategis pengembangan wilayah kabupaten/kota yang sesuai dengan fungsi dan perannya di dalam rencana struktur dan rencana pola operasional

Tabel 1.1 Kedudukan RTRW Kabupaten Dalam Sistim Penataan Ruang dan Sistim Perencanaan Pembanguan Nasional.

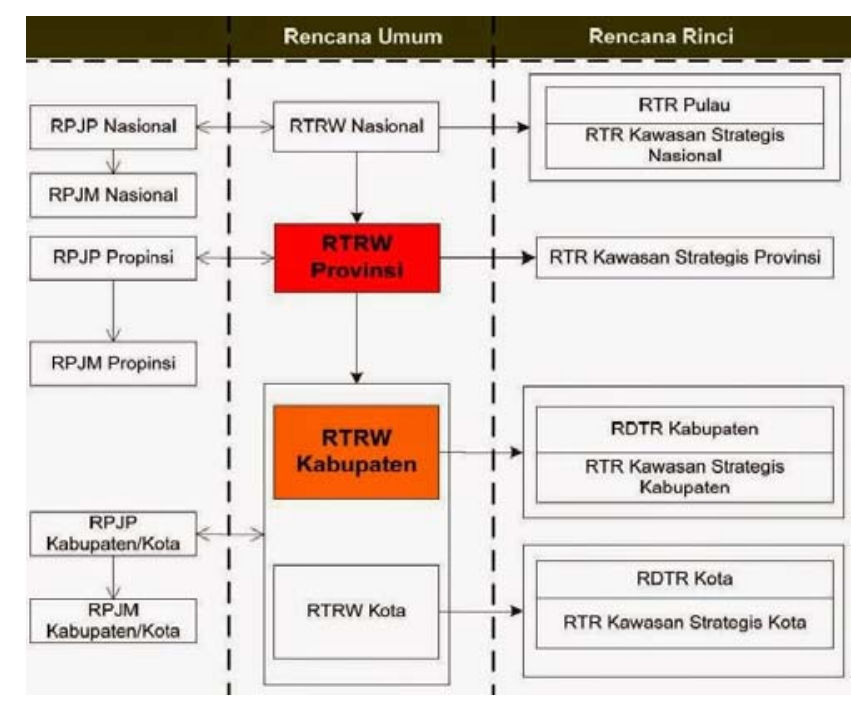

Sebagai rujukan Peraturan Daerah Nomor 1 Tahun 2017 Tentang Rencana Tata Ruang Wilayah Provinsi Kepulauan Riau disahkan pada tanggal 02 Januari 2017 dengan demikian Peraturan Daerah Nomor 7 Tahun 2012 Tentang Rencana Tata Ruang Wilayah Kabupaten Karimun disahkan/terbit sebelum Peraturan Daerah Nomor 1 Tahun 2017 Tentang Rencana Tata Ruang Wilayah Provinsi Kepulauan Riau disahkan/terbit. Berdasarkan Pra penelitian yang dilakukan peneliti, pada Peraturan Daerah Nomor 7 Tahun 2012 Tentang Rencana Tata Ruang Wilayah Kabupaten Karimun dan Peraturan Menteri Pekerjaan Umum Nomor 
16/PRT/M/2009 tentang Pedoman Penyusunan Rencana Tata Ruang Wilayah kabupaten tidak dijadikan sebagai acuan dalam penyusunannya.

Berdasarkan pra penelitian yang dilakukan peneliti dengan menyandingkan Peraturan Daerah Nomor 7 Tahun 2012 Tentang Rencana Tata Ruang Wilayah Kabupaten Karimun dengan Peraturan Daerah Nomor 1 Tahun 2017 Tentang Rencana Tata Ruang Wilayah Provinsi Kepulauan Riau terdapat ketidak sesuaian pola ruang dan peruntukan kawasan yang dapat menimbulkan berbagai interprestasi dimasyarakat dan pemangku kepentingan yang ada. Dengan adanya ketidak sesuaian ini, menimbulkan tidak adanya kepastian hukum dan efektivitas anggaran dalam pelaksanaan Peraturan Daerah Nomor 7 Tahun 2012 Tentang Rencana Tata Ruang Wilayah Kabupaten Karimun.

Merujuk dari paparan di atas penulis tertarik untuk mengambil Penelitian ini dengan judul : Analisis Yuridis Terhadap Pelaksanaan Peraturan Daerah Nomor 7 Tahun 2012 Tentang Rencana Tata Ruang Wilayah Kabupaten Karimun Yang Terbit Sebelum Diterbitkan/Disahkan Peraturan Daerah Nomor 1 Tahun 2017 Tentang Rencana Tata Ruang Wilayah Provinsi Kepulauan Riau.

\section{B. Rumusan Masalah}

1. Bagaimana dampak kepastian hukum terhadap Perda Rencana Tata Ruang Wilayah Kabupaten Karimun yang ditetapkan/disahkan sebelum ditetapkan/disahkan Perda Rencana Tata Ruang Wilayah Provinsi Kepulauan Riau?

2. Bagaimana dampak - dampak yuridis itu mempengaruhi pelaksanaan Peraturan daerah Nomor 7 Tahun 2012 Tentang Rencana Tata Ruang Wilayah Kabupaten Karimun.

3. Faktor -faktor apa yang mempengaruhi Perda Rencana Tata Ruang Wialayah Kabupaten Karimun medahului Perda Rencana Tata Ruang Wilayah Provinsi Kepulauan Riau.

\section{Metode Penelitian}

Penelitian ini dimaksudkankan untuk menganalisis permasalahan yang dirumuskan diatas, dilakukan dengan metode pendekatan Yuridis Sosiologis. Yuridis Sosiologis adalah penelitian hukum yang mengunakan data sekunder sebagai data awalnya, kemudian dilanjutkan dengan data primer atau data lapangan, meneliti kepastian hukum suatu regulasi dan peneliti ingin mencari hubungan (korelasi) antara berbagai gejala atau variabel sebagai alat pengumpul datanya terdiri dari study dokumen, pengamatan, (observasi) dan wawancara (interview)

Pendekatan Yuridis Sosiologis diarahkan pada kenyataan dengan cara melihat penerapan hukum dalam hal ini Undang-undang Nomor 26 Tahun 2007 Tentang Penataan Ruang. Peneliti memilih penelitian hukum ini kareana peneliti melihat adanya kesenjangan antara aturan hukum yang di kehendaki (Das Sollen ) 
dengan realita yang terjadi (Das Sein) seputar kepastian hukum terkait dengan implementasi Pelaksanaan Peraturan Daerah Nomor 7 tahun 2007 Tentang Rencana Tata Ruang Wilayah Kabupaten Karimun.

Untuk menjawab permasalahan dalam penelitian ini, peneliti akan melakukan beberapa tahap penelitian sebagai berikut :

1. Penelitian dilapangan, dimana ada ketidak sesuaian pola ruang dan struktur ruang pada peta yang ada pada Peraturan Daerah Nomor 7 tahun 2007 Tentang Rencana Tata Ruang Wilayah Kabupaten Karimun dengan Peraturan Daerah Nomor 1 tahun 2017 Tentang Rencana Tata Ruang Wilayah Provinsi Kepulauan Riau

2. Penelitian tentang perundang-undangan yang terkait dengan Penataan Ruang.

Penelitian ini adalah penelitian hukum sosiologis, maka data yang digunakan adalah data primer dan skunder. Data Primer diperoleh dari hasil wawancara dan observasi sedangkan data sekunder diperoleh dari bahan-bahan hukum primer dan skunder yaitu :

\section{Data Primer}

Penelitian dilakukan di Kabupaten Karimun pada beberapa lokasi pola ruang dan sruktur pola ruang dengan membandingkan peta pola ruang pada Peraturan Daerah Nomor 7 tahun 2012 Tentang Rencana Tata Ruang Wilayah Kabupaten Karimun dengan Peraturan Daerah Nomor 1 tahun 2017 Tentang Rencana Tata Ruang Wilayah Provinsi Kepulauan Riau. Pemilihan sample dilakukan secara Purposive sampling, masing-masing sebanyak 8 lokasi. Penentuan sample didasarkan atas pertimbangan ketidaksesuaian pola ruang di Peraturan Daerah Nomor 7 tahun 2012 Tentang Rencana Tata Ruang Wilayah Kabupaten Karimun dengan Peraturan Daerah Nomor 1 tahun 2017 Tentang Rencana Tata Ruang Wilayah Provinsi Kepulauan Riau sehingga berdampak negative pada efektifitas anggaran dan kepastian hukum. Data Primer diperoleh melalui metode wawancara dan observasi dilapangan.

\section{Data Sekunder}

a. Bahan Hukum Primer

Bahan hukum primer, adalah bahan hukum yang mengikat yang terdiri dari peraturan perundang-undangan yang relevan dengan permasalahan. Bahan hukum primer dalam penelitian ini berasal dari perundang -undangan yang berkaitan dengan objek penelitian hukum yang dilakukan, yaitu :

1) Undang-Undang Dasar Negara Republik Indonesia Tahun 1945

2) Undang-Undang Nomor 26 tahun 2007 tentang Penataan Ruang (Lembaran Negara Republik Indonesia Tahun 2007 Nomor 68, Tambahan Lembaran Negara Republik Indonesia Nomor 4725)

3) Undang-undang Republik Indonesia Nomor 12 Tahun 2011 Tentang Pembentukan Perauran Perundang-undangan 
4) Peraturan Pemerintah Nomor 15 Tahun 2010 Tentang Penyelenggaraan Penataan Ruang (Lembaran Negara Republik Indonesia Tahun 2010 Nomor 20, Tambahan Lembaran Negara Republik Indonesia Nomor 5103)

5) Peraturan Presiden Republik Indonesia Nomor 87 Tahun 2011 Tentang Rencana Tata Ruang Kawasan Batam, Bintan, dan Karimun

b. Bahan Hukum Sekunder

Bahan Hukum sekunder adalah bahan-bahan yang memberikan penjelasan mengenai bahan hukum primer. bersumber dari penelitian perpustakaan, baik literatur, dokumen informasi, media cetak, internet dan kajian perundang-undangan yang berhubungan dengan objek penelitian hukum yang dilakukan.

c. Bahan Hukum Tersier

Bahan Hukum tersier adalah bahan hukum yang memberikan informasi dan penjelasan terhadap bahan hukum primer dan sekunder, meliputi : Kamus Hukum, Kamus Besar Bahasa Indonesia, Kamus Bahasa Inggris, Ensikopedia dan lain-lain.

\section{Teknik Pengumpulan Data}

Untuk memperoleh data-data yang diperlukan dalam penelitian ini disesuaikan dengan metode pendekatan dan jenis data yang dipergunakan. Maka teknik pengumpulan data yang digunakan adalah ;

\section{Wawancara}

Ditujukan dengan mengunakan tanya jawab langsung dengan metode wawancara tidak terstruktur yang ditujukan langsung kepada pihak pihak yang terkait. Wawancara dilakukan dengan beberapa sumber yaitu Kapala Bidang Perencanaan, infrastruktur, Pengembangan Wilayah dan Lingkungan Hidup, Baperlitbang Kabupaten Karimun, Kasubbid Tata Ruang Bapeda Propinsi Kepulauan Riau. Sekretaris Pansus Perda Tata Ruang Kabupaten Karimun.

Komisi II DPRD Kabupaten Karimun, Kabid Tata Ruang Dianas Pekerjaan Umum dan Tata Ruang Kabupaten Karimun, dan pihak-pihak terkait dengan maksud menguatkan data dan memperoleh informasi yang lebih mendalam mengenai permasalahan yang ada.

\section{Pengamatan (Observasi )}

Pengamatan ini dilakuakan dengan cara pengamatan langsung pada lokasilokasi pola ruang dan struktur ruang yang berobah pada Peraturan Daerah Nomor 1 Tahun 2017 Tentang Rencana Tata Ruang Wilayah Provinsi Kepulauan Riau. 


\section{Studi Dokumen}

Peneliti melakukan studi dokumen terhadap buku-buku dan literaturliteratur yang berhubungan dengan penelitian ini untuk memperoleh landasan teoritis yang dapat digunakan untuk menganalisis kepastian hukum dan efektivitas terkait Peraturan Daerah Nomor 7 Tahun 2012 Tentang Rencana Tata Ruang Wilayah Kabupaten Karimun.

Metode Analisis Data

Pengolahan dan Analisis data pada penelitian hukum sosiologis, tunduk pada cara analisis data ilmu-ilmu sosial. Untuk menganalisis data, tergantung pada sifat data yang dikumpulkan oleh peneliti. Metode analisa data yang digunakan pada penelitian ini adalah mengunakan metode pendekatan kualitatif, yaitu suatu pembahasan yang digunakan dengan cara memadukan antara penelitian perpustakaan dengan dan penelitian dilapangan. Penelitian kepustakaan dan penelitian dilapangan. Penelitian kepustakaan yang dilakukan adalah membandingkan peraturan -peraturan, ketentuan ketentuan, dan buku referensi, serta data yang diperoleh, kemudian dianalisis secara kualitatif yang akan memberikan gambaran menyeluruh tentang aspek hukum yang berhubungan dengan masalah yang diteliti.

Data yang diperoleh dari penelitian ini dianalisis secara yuridis kualitatif dengan mengunakan metode berfikir dedukatif (umum-khusus), yaitu dengan menjabarkan, menafsirkan dan mengkonstriksikan data yang diperoleh berdasarkan norma atau kaidah-kaidah, teori-teori, pengertianpengertian hukum dan doktrin-doktrin yang ada dalam dokumen, Peraturan perundang-undangan, untuk menjawab permasalahan yang ada. Analisis data yang dilakukan secara bertahap, sehingga sehingga kekurangan data penelitian secepatnya dapat di ketahui dengan cara menganalisis permasalahan yang ada dilapangan yakni mengenai Peraturan Daerah Nomor 7 Tahun 2012 Tentang Rencana Tata Ruang Wilayah Kabupaten Karimun yang diterbitkan/disahkan sebelum terbit/disahkan Peraturan Daerah Nomor 1 Tahun 2017 Tentang Rencana Tata Ruang Wilayah Provinsi Kepulauan Riau dikaitkan dengan efektivitas anggaran dan kepastian hukum terhadap penyusunan Peraturan Daerah Rencana Tata Ruang Wilayah Kabupaten Karimun, adanya kesenjangan antara hukum normatif (Das Sollen) dengan pelaksanaan norma-norma hukum (Das Sein) di dalam penyusunan Peraturan Daerah Nomor 7 Tahun 2012 Tentang Rencana Tata Ruang Wilayah Kabupaten Karimun, dalam hal ini hukum dikonsepsikan secara sosiologis sebagai suatu gejala emperis yang dapat diamati. 


\section{Hasil Penelitian Dan Pembahasan} Hasil Penelitian Di Lapangan

a) Hasil Wawancara

Hasil wawancara yang dilakukan oleh peneliti terhadap objek penelitian pada dinas/badan yaitu Badan Perencanaan dan Penelitian Pembangunan, dinas Pekerjaan Umum dan Penataan Ruang Provinsi Kepulauan Riau, Dinas Pekerjaan Umum dan Penataan Ruang Kabupaten Karimun, dan Dewan Perwakilan Rakyat daerah Kabupaten Karimun serta masyarakat yang terkena dampak. Adapun hasil wawancara sebagai mana diuraikan sebagai berikut :

1)Kepala Bidang Perencanaan, Infrastruktur, Pengembangan Wilayah Dan Lingkungan Hidup, Baperlitbang ( Bapak Heru Sunarji, ST,MM ) Tanggal 10 September 2018

Menurut bapak Heru Sunarji, melihat dari aturan perundang-undangan, salah satu keselarasan penyusunan rencana tata ruang tata wilayah idealnya dimulai dari tingkat nasional. Kemudian dituangkan ke rencana tata ruang tata wilayah provinsi dan kabupaten/kota. Dalam kondisi praktis agak sulit tercapai karena adanya berbagai macam alasan dan kendala, sehingga perda rencana tata ruang tata wilayah kabupaten Karimun mendahului perda rencana tata ruang tata wilayah provinsi. Dan itu sudah menjadi pembahasan ditingkat nasional, ini tidak terjadi dikabupaten Karimun saja tetapi terjadi juga pada kabupatenkabupaten lain di Indonesia. Menurut kajian dari bagian hukum Kementrian Pekerjaan Umum Dan Perumahan Rakyat masih diperkenankan, dengan catatan :

1. Rencana tata ruang tata wilayah disetujui ditingkat kabupaten oleh Dewan Perwakilan Daerah

2. Selanjutnya di evaluasi diprovinsi dan pada saat itu lah provinsi menilai kelayakan tata ruang wilayah kabupaten

3. Selanjutnya akan dievaluasi lagi ditingkat nasional

Apabila perda rencana tata ruang tata wilayah kabupaten mendahului perda rencana tata ruang tata wilayah provinsi, maka provinsi harus melihat perda rencana tata ruang tata wilayah kabupaten, walau ini terbalik dengan harapan agar ada keselarasan. Tidak menutup kemungkinan perda rencana tata ruang tata wilayah provinsi yang disahkan akan ada sedikit pergeseran karena adanya keadaan tertentu dan perkembangan teknologi serta perubahan-perubahan perencanaan pembangunan untuk hal-hal yang terjadi seperti itu dibolehkan, namun ketika kabupaten melakukan revisi maka harus mengikuti perda rencana tata ruang tata wilayah provinsi yang sudah ada. Untuk izin-izin yang sudah dikeluarkan masih tetap berlaku karena perda rencana tata ruang tata wilayah kabupaten masih sah sampai Perda Rencana Tata Ruang Tata Wilayah direvisi. Ketika provinsi melakukan perubahan terhadap tata ruang wilayah kabupaten, maka, provinsi harus melakukan kajian terhadap rencana tata ruang 
wilayah yang berubah itu. Apabila terjadi perubahan, maka hak-hak dan kewajiban yang diakibatkan dari perubahan pola ruang dari perda yang diterbitkan, diatur pada aturan peralihan dari perda tersebut.

Dengan demikian juga ada kewenangan yang berubah, akibat dari perubahan pola ruang yang ada, seperti dari pola ruang kawasan pertanian diubah menjadi kawasan pertambangan, maka perizinannya berada di provinsi namun untuk pengesahan perizinan dari provinsi tetap harus mendapat rekomendasi dari kabupaten.

Faktor yang menyebabkan perda rencana tata rung tata wilayah kabupaten mendahului perda rencana tata ruang wilayah provinsi karena provinsi menunggu padu serasi hutan dari kementrian ATR sementara kabupaten harus segera menyusun perda rencana tata ruang tata wilayah karena itu akan berdampak pada jalannya pemerintahan dan investasi yang akan masuk ke kabupaten.

\section{2) Kasubbid Tata Ruang Bapeda Provinsi Kepulauan Riau ( Ibu Evy Yusriani,M.SC ) Tanggal 13 September 2018}

Menurut ibu Evy rencana tata ruang provinsi masih menunggu hasil padu serasi hutan, karena hutan yang ada di kepulauan riau merupakan pecahan dari provinsi Riau, terkait dengan proses percepatan penyelesaian tata ruang daerah, pada 6 Juli 2011 keluar Surat Edaran dari Kementrian Dalam Negeri Nomor 650/3093/IV/Bagda. Surat ini menginstruksikan seluruh kepala daerah baik di provinsi maupun kabupaten untuk mempercepat proses penetapan perda. Berdasarkan surat edaran ini lah kabupaten yang ada di provinsi Kepulauan Riau yaitu Kabupaten Bintan, Kabupaten Karimun, Dan Kabupaten Lingga memperdakan Rencana Tata Ruang Tata Wilayah Kabupaten karena Rencana Tata Ruang Provinsi belum ada maka rencana tata ruang kebupaten merujuk pada Rencana Tata Ruang Nasional. Kemudian diperkuat peraturan presiden republik Indonesia Nomor 87 Tahun 2011 Tentang Rencana Tata Ruang Kawasan Batam, Bintan, dan Karimun pada tanggal 2 Desember 2011. Kemudian terbit surat Keputusan Mentri Kehutanan 463/menhud-II/2013 yang kemudian digugat oleh masyarakat Bintan Dan Karimun. Karena detil komposis luasan hutan dan nonhutan wilayah DPCLS yang telah di setujui DPRRI. Maka mentri LHK melakukan penyesuaian maka terbitlah SK76/MenLHK-II/2015. Surat keputusan (SK) Menhut Nomor : SK.76/MenLHK-II/2015 tentang perubahan peruntukan kawasan menjadi bukan kawasan hutan menjadi kawasan hutan dari provinsi Kepulauan Riau (KEPRI) dilakukan secara transfaran dan partisifatif. Surat keputusan ini merupakan keputusan terhadap padu serasi hutan provinsi Kepulauan Riau. Maka pada tanggal 2 Januari 2017 terbitlah Perda Rencana Tata Ruang Provinsi Nomor 1 Tahun 2017. 


\section{3) Sekretaris Pansus Perda Tata Ruang Kabupaten Karimun (Anwar Abu Bakar) Tanggal 14 September 2018}

Untuk berjalannya suatu pemerintahan maka diperlukan suatu acuan, untuk memenuhi acuan tersebut maka kita harus membuat satu aturan yang disebut perda. Salah satu nya yaitu perda rencana tata ruang wilayah. Perda RTRW kabupaten merupakan penjabaran dari RTRW provinsi, karena provinsi belum menyusun ranperda RTRW provinsi disebabkan beberapa faktor, selain belum selesainya paduserasi juga ada tarik ulur kepentingan politik, maka kita mengacu pada RTRW nasional. Walaupun RTRW provinsi

belum ada, RTRW kabupaten disahkan secara legalitas tetap sah karena itu merupakan amanat dari undang-undang.

Dengan terbitnya perda rencana tata ruang tata wilayah provinsi nomor 1 tahun 2017 terjadi perubahan pola ruang. Menurut pendapat saya wajar saja berubah karena perkembangan dari pertumbuhan penduduk dan perkembangan teknologi bisa mempengaruhi pula ruang yang ada. Namanya sebuah aturan dalam penerapannya tentu perlu acuan yang tidak berubah-ubah, supaya ada kepastian hukum. Perubahan itu sudah biasa terjadi dan itu bukan saja ditata ruang tapi di beberapa hal termasuk orang yang membuat draf undang-undang di pusat. Dan saya berpandang selama itu sesuai dan bisa di terapkan dan dilaksanakan. Kita sering mengatakan tidak konsistennya suatu keputusan yang satu bertentangan dengan yang lainnya kita bisa memaklumi mungkin saja itu kealpaan si pembuat atau juga unsur politik sebagai contoh terbitnya suatu undang-undang tapi pelaksanaan nya diatur dengan peraturan pemerintah. Tapi setelah beberapa tahun ternyata PP nya tidak pernah diterbitkan sampai berganti masa pemerintahan.

\section{4)Kabid Tata Ruang Dinas Pekerjaan Umum Dan Tata Ruang Kabupaten Karimun (Faisal Rizal, ST.M.A.P) Tanggal 15 September 2018}

Dengan terbitnya perda rencana tata ruang provinsi nomor 1 tahun 2017, terjadi beberapa perubahan pola ruang di kabupaten karimun. Terkait rekomendasi izin yang dikeluarkan oleh Dinas Pekerjaan Umum dan Penataan Ruang Kabupaten Karimun tidak lagi mengeluarkan izin pada lokasi yang berubah sampai revisi perda RTRW kabupaten Karimun. Jika seandainya ada rekomendasi yang sudah dikeluarkan sebelum disahkan perda RTRW provinsi maka surat izin masih berlaku sampai perda RTRW selesai direvisi, kemudian perizinan itu diperbarui kembali untuk di sesuaikan dengan peruntukan yang baru. Begitu juga untuk perizinan yang baru yang peruntukannya berubah maka untuk sementara dihoul. Salah satu contoh, jika seandainya ada perubahan pola ruang pada kawasan perindustrian dan disana sudah ada rumah masyarakat untuk itu kita akan melakukan rekayasa teknik, tanpa merelokasi rumah tersebut, karena $30 \%$ dari kawasan itu merupakan kawasan tempat 
tinggal untuk karyawan. Jika tidak memungkinkan untuk dilakukan rekayasa teknik, maka harus direlokasi dengan memberikan ganti rugi.

\section{5) Masyarakat ( terdampak ) Tanggal 17 September 2018}

Sebagai masyarakat kami masyarakat Jelutung Kelurahan Darusalam Kecamatan Meral Barat sangat kecewa dengan adanya perubahan yang terjadi pada tata ruang dulu lahan kami berada didaerah putih tapi dengan adanya permen LHK nomor 76 tahun 2015 sekarang menjadi kawasan hutan, kami sudah melakukan mediasi ke beberapa instansi pemerintah agar permasalahan ini bisa diselesaikan. Sehingga kami bisa memanfaatkan lahan yang kami punya, agar tidak terjadi perselisihan dengan pejabat pemerintah yang punya wewenang. Kami berharap pemerintah lebih peka terhadap kesejahteraan masyarakat, sehingga kami bisa hidup tenang dan mencari nafkah.

\section{b) Hasil Observasi}

Dari hasil Observasi di lapangan terdapat beberapa perubahan pola ruang pada Perda Rencana Tata Ruang Wialayah Kabupaten Karimun dengan Perda tata Ruang Wilayah Provinsi sebagai berikut :

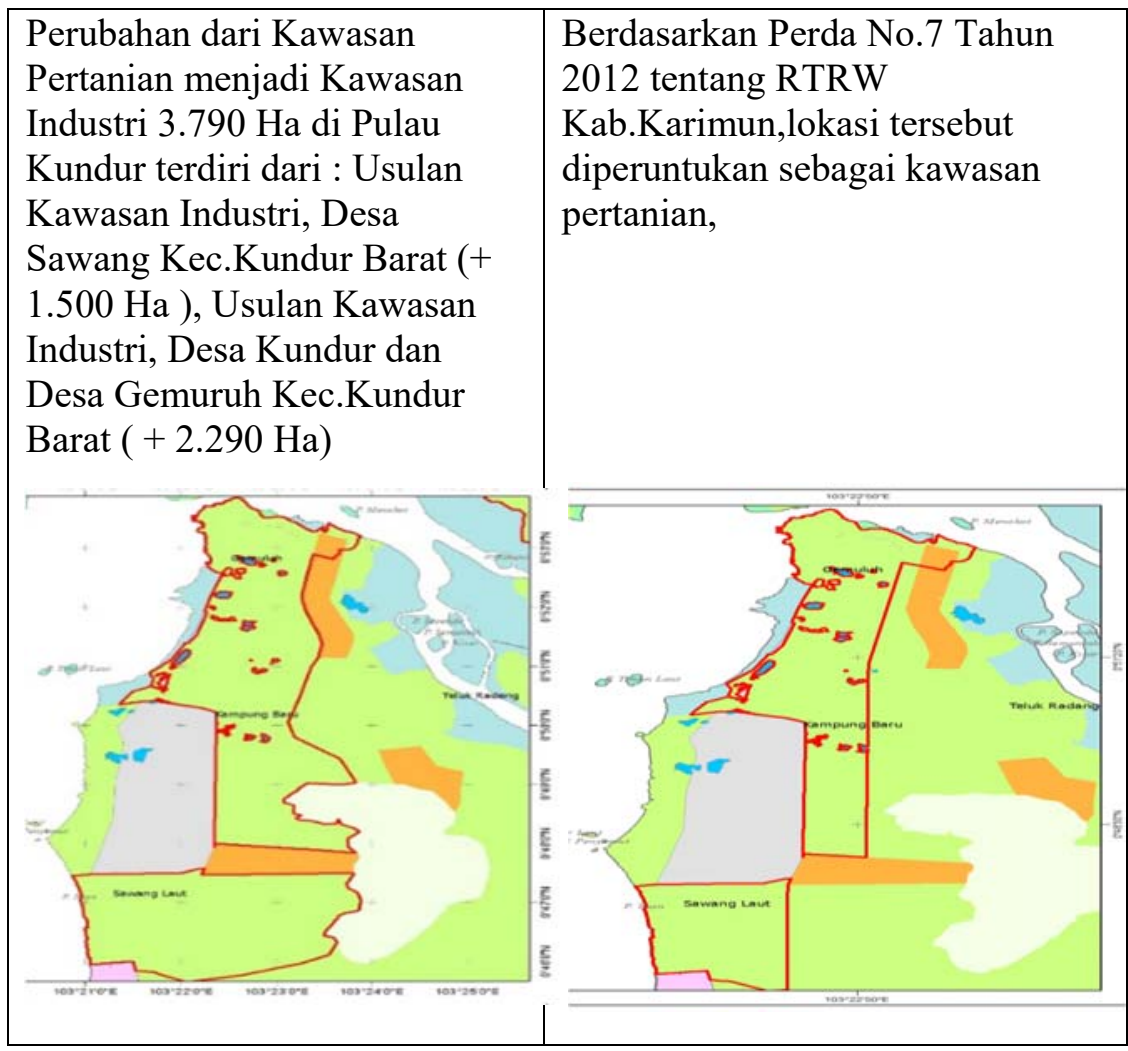

Gambar 3. 1 Hasil Observasi 




Gambar 3. 2 Hasil Observasi 


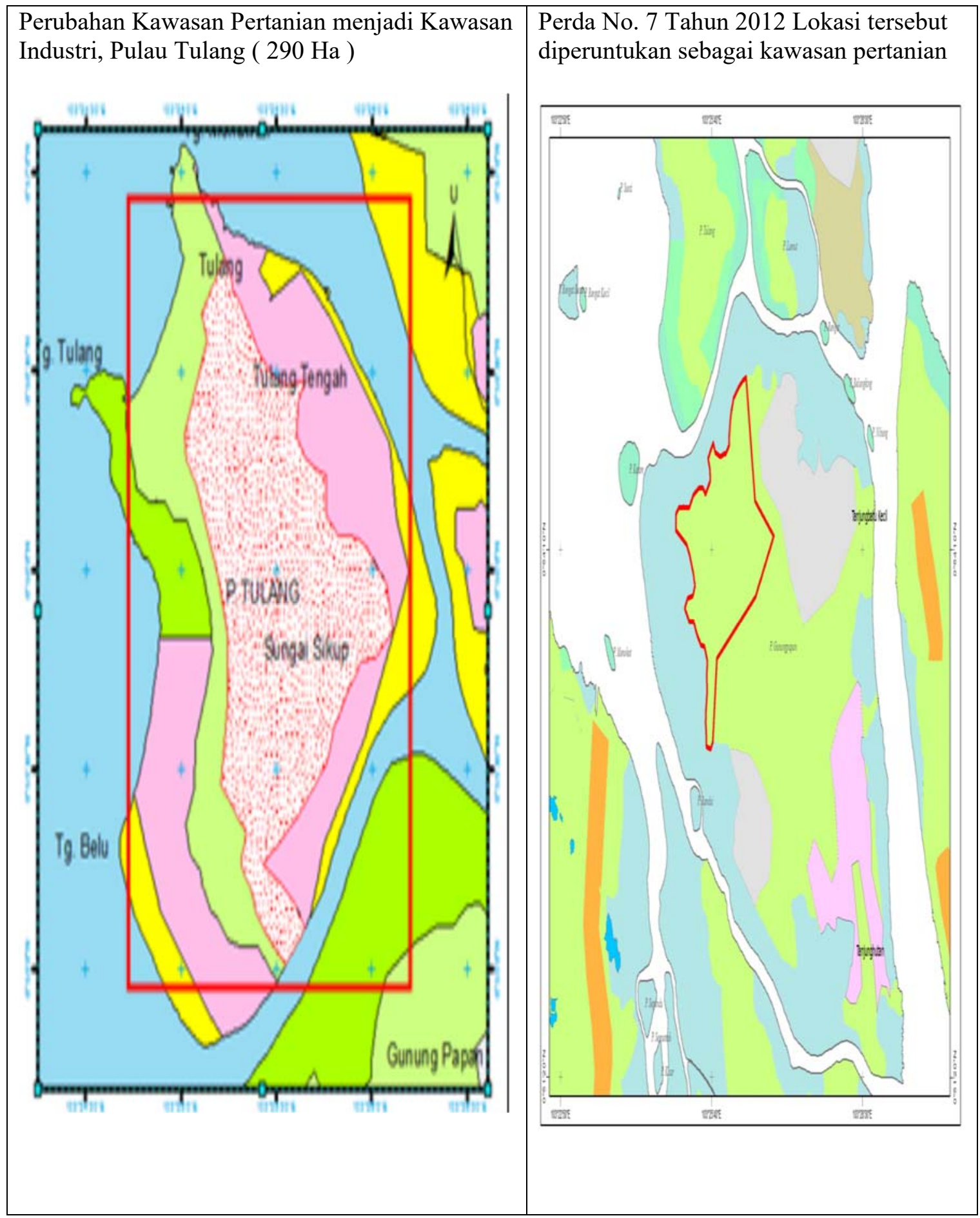

Gambar 3. 3 Hasil Observasi 




Gambar 3. 4 Hasil Observasi 


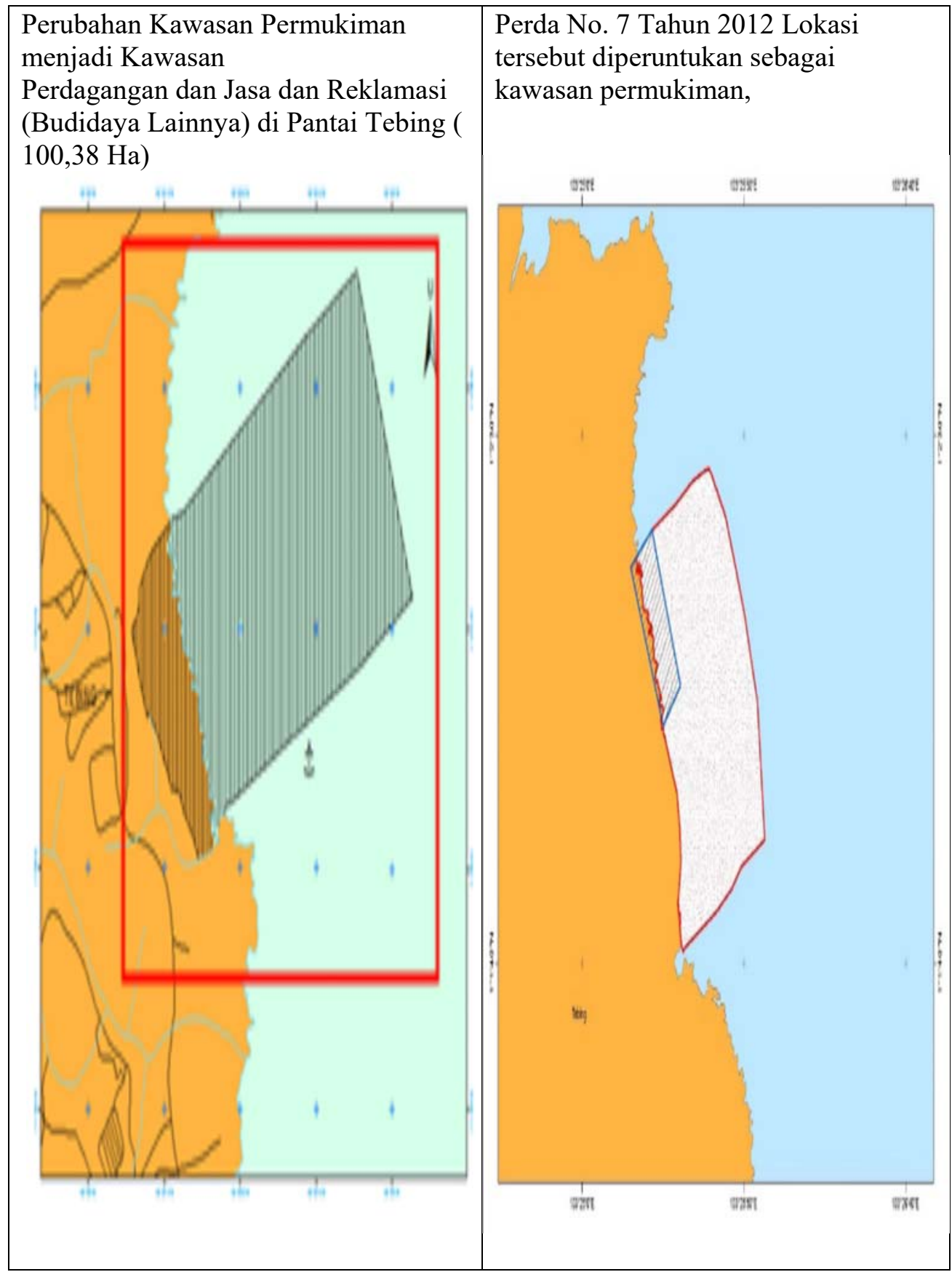

Gambar 3. 5 Hasil Observasi 




Gambar 3. 6 Hasil Observasi 




Gambar 3. 7 Hasil Observasi 


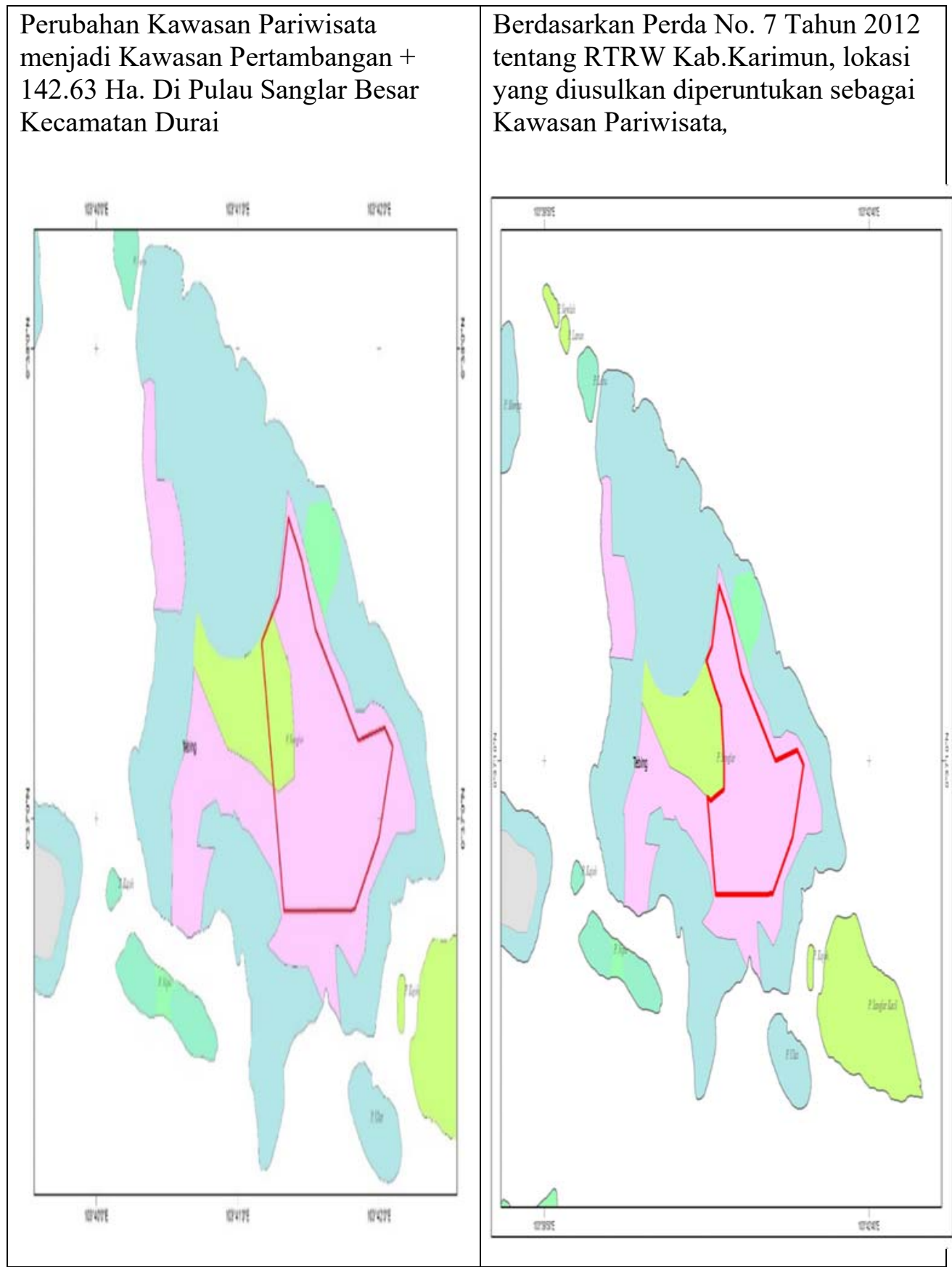

Gambar 3. 8 Hasil Observasi 


\section{HASIL PENELITIAN PUSTAKA DAN STUDY DOKUMEN}

Undang-undang dasar 1945 beserta amandemen ke 2 tahun 2000 sebagai landasan dasar konstitusional. Negara kesatuan republik Indonesia (NKRI) terdiri atas daerah-daerah provinsi dan daerah provinsi dibagi atas kabupaten dan kota disetiap provinsi, kabupaten dan kota mempunyai pemerintah daerah yang diatur dengan undang-undang. Dalam sistem NKRI, provinsi merupakan subsistem NKRI dan kabupaten atau kota merupakan sub-sub sistem NKRI.

Pada dasarnya otonomi merupakan penyerahan kewenangan bukan kedaulatan dari pemerintah pusat kepada daerah, untuk lebih memberdayakan daerah, mensejahterakan masyarakat serta untuk memdapatkan perpaduan yang maksimum dalam pengelolaan pembangunan daerah dan nasional demi tercapainya integritas dalam upaya menyelaraskan nilai efesiansi dan dalam praktek penyelenggaraan pemerintah terdapat hubungan koordinasi, kerja sama dan atau kemitraan antara daerah provinsi dengan daerah kabupaten dan daerah kota dalam kedudukan masing-masing sebagai daerah otonom, ini berarti antara provinsi dengan kabupaten dan kota ada keterikatan satu sama lain dalam arti status kewilayahan maupun dalam sistem dan prosedur penyelenggaraan pemerintahan, karena kabupaten/ kota penyusunannya dilandasi oleh wilayah Negara yang disatukan sebagai wilayah provinsi sebagai unsur perekat NKRI.

Dalam sistem ruang, wilayah nasional, wilayah provinsi, wilayah kabupaten dan kota merupakan subsistem ruang sebagai suatu kesatuan wilayah. Pengelolaan subsistem ruang saling berpengaruh pada subsistem yang lain yang pada akhirnya akan mempengaruhi sistem ruang secara keseluruhan, oleh karena itu pengaturan ruang harus dikembangkan suatu sistem keterpaduan sebagai ciri utamanya. Penataan ruang sebagai proses perencanaan tata ruang, pemanfaatan ruang, dan pengendalian pemanfaatan ruang merupakan satu kesatuan sistem yang tidak dapat dipisahkan antara satu dengan yang lainnya

Dalam rangka mengoptimalkan konsep penataan ruang, maka peraturanperaturan perundang-undang telah banyak diterbitkan oleh pihak pemerintah, dimana salah satu peraturan perundang-undangan yang mengatur penataan ruang adalah Undang-undang Nomor 26 tahun 2007 Tentang Penataan ruang, merupakan undang-undang pokok yang mengatur tentang pelaksanaan panataan ruang.

Dengan adanya undang undang tersebut diharapkan selain sebagai konsep dasar hukum dalam pelaksanaan perencanaan tata ruang jaga diharapkan dapat digunakan sebagai bahan acuan pemerintah dalam penataan ruang. Undang-undang No. 26 Tahun 2007 tentang penataan ruang pasal 18, menyatakan bahwa penetapan rancangan peraturan daerah provinsi tentang rencana tata ruang wilayah provinsi dan rencana rinci tata ruang terlebih dahulu harus mendapat persetujuan substansi dari menteri; Penetapan rancangan peraturan daerah kabupaten/kota tentang rencana tata ruang wilayah kabupaten/kota dan rencana rinci tata ruang terlebih 
dahulu harus mendapat persetujuan substansi dari menteri setelah mendapatkan rekomendasi gubernur. Dan menteri yang menangani penataan ruang melalui badan koordinasi tata ruang nasional (BKPRN), yaitu Menteri Pekerjaan Umum sebagai ketua tim pelaksana BKPRN.

Undang-undang Penataan Ruang merupakan formalisasi kegiatan perencanaan pemanfaatan ruang di Indonesia, yang berarti bahwa pada setiap aktivitas pembangunan, proses penyusunan rencana, legalisasi dan implementasinya, didasarkan atas jalur-jalur legal formal yang telah ditetapkan. Untuk itu, selain disyaratkan memenuhi unsur-unsur legal formal dan filosofis.

Rencana tata ruang wilayah lebih jelas diatur lebih jelas dalam pasal 18 , pasal 23, pasal 25, pasal 26, undang-undang nomor 26 tahun 2007 tentang penataan ruang berdasarkan ketentuan terdapat lima hal yang terkandung di dalamnya yaitu :

1. Rencana tata ruang wilayah provinsi menjadi pedoman untuk :

a. penyusunan rencana pembangunan jangka panjang daerah

b. penyusunan rencana jangka menengan daerah

c. pemanfaatan ruang dalam pengendalian pemanfaatan ruang dalam wilayah provinsi

d. mewujudkan keterpaduan, keterkaitan, dan keseimbangan perkembangan antar wilayah kabapaten/kota serta keserasian antar sektor

e. penetapan lokasi dan fungsi ruang untuk investasi

f. penetapan ruang kawasan strategis provinsi dan

g. penataan ruang wilayah kabupaten/kota (pasal 23 ayat 2)

2. Penyusunan rencana tata ruang wilayah kabupaten harus memperhatikan :

a. perkembangan permasalahan provinsi dan hasil pengkajian implementasi penataan ruang kebupaten

b. upaya pemerataan pembangunan dan pertumbuhan ekonomi kabupaten

c. keselarasan aspirasi pembangunan kabupaten

d. daya dukung dan daya tampung lingkungan hidup

e. rencana pembangunan jangka panjang daerah

f. rencana tata ruang wilayah kabupaten yang berbatasan, dan

g. rencana tata ruang kawasan strategis kabipaten (pasal 25 ayat 2).

Selanjutnya pada pasal 78 ayat (4b) dan (4c) dinyatakan bahwa semua peraturan daerah provinsi tentang rencana tata ruang wilayah provonsi disusun atau disesuaikan paling lambat dalam waktu 2 ( dua ) tahun dan untuk peraturan daerah kabupaten / kota tentang rencana tata ruang wilayah kabupaten / kota disusun atau disesuaikan paling lambat 3 ( tiga ) tahun terhitung sejak undang - undang tersebut diberlakukan. Dengan demikian dicermati adalah :

1. Penyesuaian Rencana Tata Ruang Wilayah dengan Undang - undang No 26 tahun 2007 dan peraturan - peraturan di bawahnya ( peraturan pemerintah dan petunjuk teknisnya ) 
2. Legalisasi Rencana Tata Ruang Wilayah tersebut menjadi peraturan daerah yang secara yuridis formal / hukum dapat menjadi acuan dalam pelaksanaan pembangunan di daerah. Karenanya untuk mendukung proses legalisasi Rencana Tata Ruang Wilayah tersebut perlu dilakukan upaya - upaya percepatan penyesuaian penyusunan Rencana Tata Ruang Wilayah

Instruksi Presiden Republik Indonesia, Nomor 1 Tahun 2010 tentang percepatan Pelaksanaan Prioritas Pembangunan Nasional Tahun 2010 memperkuat Undang-undang Penataan Ruang Nomor 26 Tahun 2007 , dalam upaya percepatan penyelesaian Raperda Rencana Tata Ruang Wilayah. Sehubungan dengan itu dan dalam rangka persetujuan substansi dari Menteri Pekerjaan Umum tentang Rencana Tata Ruang Wilayah, melalui kegiatan Pendamping Teknis Percepatan Penyusunan Raperda Rencana Tata Ruang Wilayah, maka Direktorat Jenderal Penataan Ruang memandang perlu untuk melaksanakan kegiatan pendampingan teknis dalam rangka percepatan penyusunan Rencana Tata Ruang Wilayah kabupaten.

Rencana Tata Ruang baik Rencana Tata Ruang Wilayah Provinsi, Kabupaten maupun kota merupakan syarat yang diperlukan untuk beberapa hal sebagai berikut :

a. Meminimalkan konflik antar kegiatan

b. Menjamin keberlanjutan kegiatan

c. Mendorong terjadinya efisiensi kegiatan yang lebih tinggi

d. Menjamin kepastian investasi kegiatan

Rencana Tata Ruang merupakan suatu bentuk kesepakatan publik dan mengikat sebagai suatu kontrak sosial atau suatu bentuk keputusan kolektif yang dihasilkan dari proses politik dan kemudian menjadi kebijakan publik yang harus ditaati oleh seluruh pelaku pembangunan.

Peraturan daerah adalah peraturan perundang-undangan yang dibentuk oleh dewan Perwakilan Rakyat Daerah dengan persetujuan bersama Kepala Daerah ( UU No 10 tahun 2004 tentang pembentukan peraturan perundang-undangan dan UU RI no 12 Tahun 2011 tentang pembentukan peraturan perundangundangan ). Peraturan Daerah tentang Rencana Tata Ruang Wilayah adalah peraturan perundang-undangan yang mengatur tentang Rencana Tata Ruang Daerah yang dibentuk oleh Dewan Perwakilan Daerah dengan persetujuan bersama Kepala Daerah

Prosedur Penyusunan Produk Hukum Daerah adalah rangkaian kegiatan penyusunan produk hukum dearah sejak perencanaan sampai dengan penetapan (Permendagri No 16 Tahun 2006 Tentang Prosedur Penyusunan Produk Hukum Daerah) dalam rangka tertib administrasi penyusunan produk hukum daerah yang diperlukan dalam penyeragaman prosedur secara terpadu dan terkoordinasi.

Adapun tujuan penyusunan Perda Rencana Tata Ruang Daerah adalah sebagai berikut : 
1. Perlindungan hukum dalam upaya memberikan aspek legalitas bagi pelaksanaan pembangunan di daerah

2. Rujukan penyelesaian masalah dalam rangka meminimalkan konflik antar kegiatan

Pelayanan publik sebagai upaya mendorong terjadinya efisiensi kegiatan yang lebih tinggi. Penataan ruang sebagai proses perencanaan tata ruang, pemanfaatan ruang, dan pengendalian pemanfaatan ruang merupakan satu kesatuan sistem yang tidak dapat dipisahkan antara satu dengan yang lainnya. Rencana Tata Ruang Wilayah (RTRW) Kabupaten Karimun di atur dengan Peraturan Daerah Nomor 7 Tahun 2012. Karena proses penyusunan perda RTRW provinsi belum terbit/disahkan maka perda RTRW kabupaten Karimun mengacu kepada RTRW nasional berdasarkan Surat Edaran Mendagri 650/3093/IV/Bagda tentang percepatan penetapan Ranperda RTRW kabupaten/kota.

Proses penyusunan telah dilakukan secara bertahap dimulai dari penjaringan aspirasi dan komunikasi dengan pelaku-pelaku pembangunan terkait secara bertahap dan berulang, baik dengan pemeintah pusat, provinsi tetangga, kabupaten/kota, representatif dunia usaha , perguruan tinggi, masyarakat dan press sehingga pada akhirnya pada akhirnya dapat dicapai suatu kesepakatan dan disahkan menjadi perda.

Arahan Kebijakan RTRW Kabupaten Karimun terhadap Undang-Undang Nomor 26 tahun 2007 tentang Penataan Ruang memandatkan pemerintah daerah, baik provinsi maupun kabupaten, untuk segera menyelesaikan RTRW dalam waktu 2 tahun, namun Provinsi Kepulauan Riau baru terlaksana setelah 10 (sepuluh) tahun Undang-Undang Nomor 26 tahun 2007 tentang Penataan Ruang diundangkan. Dengan diterbitkannya Perda Nomor 1 Tahun 2017 tentang Rencana Ruang Wilayah Provinsi Kepulauan Riau. Karena Proses padu serasi antara Tata Guna Hutan sesuai kesepakatan Peraturan Menteri Kehutanan Republik Indonesia Nomor : P. 50/Menhut-II/2009 Tentang Penegasan Status Dan Fungsi Kawasan Hutan yang merupakan dasar bagi keruangan kawasan hutan dan RTRW Provinsi Kepulauan Riau tidak pernah berjalan dengan baik. Hal inilah yang membuat RTRW, Provinsi Kepualauan Riau mengalami kendala didalam mendapatkan persetujuan untuk kemudian bisa dimasukkan dalam bentuk Peraturan Daerah. Meskipun demikian Kementerian Kehutanan berusaha untuk memutakhirkan kondisi kawasan hutan terkini. Kemudian diperkuat dengan Peraturan Presiden Republik Indonesia nomor 87 tahun 2011 tentang rencana tata ruang kawasan Batam, Bintan, dan Karimun pada tanggal 2 Desember 2011.SK ini dihasilkan atas pertimbangan tim terpadu untuk penyelesaian permasalahan padu serasi di Provinsi Kepulauan Riau. Proses pengukuhan kawasan hutan mestinya dilakukan dengan memperhatikan rencana tata ruang wilayah yang ada di provinsi maupun kabupaten. Dengan kata lain, agar proses padu serasi berjalan dengan baik, kawasan hutan sebelumnya harus dikukuhkan melalui proses mulai dari penunjukkan kawasan hutan, penataan batas, pemetaan dan 
penetapan kawasan hutan. Terkait dengan proses percepatan penyelesaian Tata Ruang daerah, pada 6 Juli 2011 keluar Surat Edaran Kemendagri 650/3093/IV/Bangda tentang Percepatan Penetapan Raperda tentang RTRW Kabupaten Kota. Surat ini menginstruksikan seluruh Kepala Daerah baik di Provinsi maupun Kabupaten untuk mempercepat proses penetapan Perda. Pada tanggal 28 Desember 2012 Bupati Karimun menetapkan Perda Nomor 7 Tahun 2012 Tentang Rencana tata Ruang Kabupaten Karimun.

Sementara Pemerintah Provinsi Kepulauan Riau menunggu RTRW Provinsi Kepulauan untuk disahkan. Terus bergulirnya proses RTRW Propinsi yang tidak kunjung usai memperlihatkan ada proses politik sumberdaya alam yang menjadikan halangan terwujudnya RTRW Propinsi Kemudian terbit surat keputusan Mentri Kehutanan nomor 463/menhut-II/2013 tentang Perubahan Peruntukan Kawasan bukan hutan menjadi kawasan hutan provinsi kepulauan Riau. Sehingga berdampak pada ketidak pastian hukum bagi masyarakat dan dunia usaha perizinan investasi di kepulauan Riau. Dampak dilapangan, terjadi konflik perencanaan dan pemanfaatan ruang akibat tumpang tindih kebijakan.

Keluarnya SK Mentri Kehutanan nomor 463/menhut-II/2013 menjadi tumpang tindih dengan Peraturan Presiden Republik Indonesia nomor 87 tahun 2011 tentang rencana tata ruang kawasan Batam, Bintan, dan Karimun yang kemudian digugat oleh masyarakat Bintan dan Karimun. Maka Mentri LHK melakukan penyesuaian dengan dikeluarkan SK76/MenLHK-II/2015 tentang Perubahan Peruntukan Kawasan Menjadi Kawasan Hutan, Perubahan Fungsi kawasan Hutan dan Perubahan Bukan Kawasan menjadi Menjadi Kawasan Hutan. Sebagai revisi terhadap Surat keputusan (SK) menhut Nomor : 463/menhut-II/2013 tentang Perubahan Peruntukan Kawasan bukan hutan menjadi kawasan hutan provinsi kepulauan Riau, dilakukan secara transfaran dan partisifatif. Surat keputusan ini merupakan keputusan terhadap padu serasi hutan Provinsi Kepulauan Riau. Maka pada Tanggal 2 Januari 2017 terbitlah Perda Rencana Tata Ruang Provinsi Kepulauan Riau Nomor 1 Tahun 2017.

Arahan penyempurnaan RTRW Kabupaten Karimun, secara keruangan dalam bentuk peta jika dibandingkan antara RTRW Kepulauan Riau ada beberapa wilayah yang overlap (tumpang tindih) antara kawasan dengan RTRW Kabupaten Karimun, misalnya seperti kawasan pertanian menjadi kawasan perindustrian, kawasan Pertanian menjadi kawasan pertambangn, dan hutan produksi menjadi permukiman.

Sebagai arahan penyempurnaan RTRW Kabupaten Karimun, berdasarkan hasil penelitian dan uraian proses penyusunan RTRW, perlu mempertimbangkan setidaknya dua hal penting agar bisa berjalan bersama dan terintegrasi dengan RTRW Provinsi Kepulauan Riau. Pertama, perlu memperhatikan kondisi eksisting yang telah digambarkan sebelumnya dalam RTRW Kabupaten. Hal ini perlu dilakukan agar penyesuaian dengan RTRW Provinsi dapat dengan mudah dilakukan. Kedua, Pemerintah Kabupaten 
Karimun agar segera melakukan revisi Perda Rencana Tata Ruang Wilayah Kabupaten Karimun.

\section{E. Kesimpulan}

Dari hasil penelitian dapat ditarik kesimpulan sebagai berikut :

1. Dampak kepastian hukum terhadap Perda Rencana Tata Ruang Wilayah Kabupaten Karimun yang ditetapkan/disahkan sebelum ditetapkan/disahkan Perda Rencana Tata Ruang Wilayah Provinsi Kepulauan Riau.

Pembentukan Peraturan Daerah Nomor 7 tahun 2012 tentang Rencana Tata Ruang Wilayah Kabupaten Karimun merupakan langkah yang tepat dalam menjalankan pemerintahan dan pembangunan di Kabupaten Karimun, akan tetapi dalam membentuk suatu kebijakan daerah harus mengacu kepada aturan yang berlaku sehingga tidak bertentangan dengan aturan yang lebih tinggi. Dengan terbitnya perda Rencana Tata Ruang Wilayah Propinsi terdapat beberapa perubahan pola ruang pada bagian bagian tertentu yang mengharuskan diadakan perubahan sehingga berampak pada kepastian Hukum terhadap legistimasi Perda RTRW Kabupaten Karimun.

2. Dampak - dampak yuridis yang mempengaruhi pelaksanaan Peraturan daerah Nomor 7 tahun 2012 Tentang Rencana Tata Ruang Wilayah Kabupaten Karimun.

Keberadaan Perda RTRW kabupaten Karimun sebagai pedoman dalam pelaksanaan tata ruang dan tata letak wilayah Kabupaten Karimun memiliki korelasi yuridis terkait keberadaan Perda RTRW Propinsi Kepulauan riau, dimana terdapat beberapa perubahan pola ruang yang terjadi mengakibatkan tumpang tindih perijinan usaha kehutanan dan non kehutanan. Terbitnya Surat Keputusan Menteri Kehutanan 463/Menhut-II /2013 yang kemudian digugat oleh masyarakat Bintan dan Karimun, Karena detil komposisi luasan hutan dan non hutan wilayah DPCLS tidak disetujui. Maka Mentri Lingkungan Hidup dan Kehutanan melakukan penyesuaian maka terbitkan Surat Keputusan 76/MenLHK-II/2015 tentang Perubahan peruntukan Kawasan bukan Kawasan Hutan, Perubahan fungsi kawasan hutan dan perubahan kawasan hutan menjadi kawasan hutan dari Provinsi Kepulauan Riau dilakukan secara transparan dan partisipatif juga tidak menyelesaikan masalah yang pada kenyataannya dilapangan masih terdapat ketidak singkronan pola ruang.

3. Bahwa faktor yang mempengaruhi penetapan Perda Rencana Tata ruang Wilayah Kabupaten Karimun yang disahkan sebelum Perda Rencana Tata Ruang Provinsi karena Provinisi karena menunggu proses paduserasi hutan dan DPCLS dari kementrian Kehutanan sementara kabupaten harus segera menyusun Perda Rencana Tata Ruang Wilayah karena itu akan berdampak pada jalannya pemerintahan dan pelayanan publik serta investor yang akan masuk ke kabupaten Karimun. Diterbitkan Peraturan Presiden Republik Indonesia Nomor 87 Tahun 2011 Tentang Rencana Tata Ruang Kawasan 
Batam, Bintan, Dan Karimun, pada tangal 2 Desember 2011 menjadi acuan untuk menyusun Perda RTRW Kabupaten Karimun. 


\section{DAFTAR PUSTAKA}

\section{Buku}

Siti Sundari Rangkuti, Hukum Lingkungan dan Kebijakan Nasional,(edisi ketiga), Surabaya : Airlangga University Press, 2005.

Hans Kelsenn, General Theory of Law and state, New York : Rasell \& Rasell, 1945.

Penjelasan Ketentuan Umum Pasal Angka 4 UU No.26 Tahun 2007 Tentang Penataan Ruang

Amiruddin, Pengantar Metode Penelitian Hukum, Jakarta: PT Rajawali Grafindo Persada, 2012.

Soerjono Soekanto, Pengantar Penelitian Hukum, Jakarta : Rajawali Perss, 1996.

Silalahi, M. Daud. Hukum Lingkungan Dalam Sistem Penegakan Hukum Lingkungan Indonesia. Bandung : Alumni Bandung, 2006. 